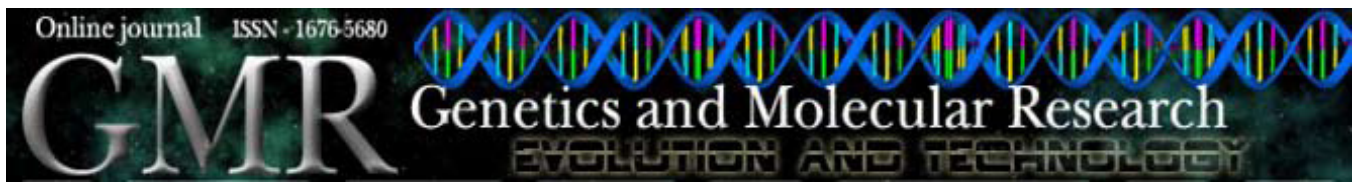

\title{
Cloning, sequencing and antigenic characterization of rVirB9 of Anaplasma marginale isolated from Paraná State, Brazil
}

\author{
M.C. Vidotto ${ }^{1}$, E.J. Venâncio ${ }^{2}$ and O. Vidotto $^{1}$ \\ ${ }^{1}$ Departamento de Medicina Veterinária Preventiva, CCA, Londrina, PR, Brasil \\ ${ }^{2}$ Departamento de Patologia, CCB, Universidade Estadual de Londrina, PR, Brasil \\ Corresponding author: M.C. Vidotto \\ E-mail: macarlos@uel.br
}

Genet. Mol. Res. 7 (2): 460-466 (2008)

Received November 14, 2007

Accepted May 8, 2008

Published June 3, 2008

\begin{abstract}
Anaplasma marginale, a tick-borne bacterium, causes bovine anaplasmosis responsible for significant economic losses in tropical and subtropical regions worldwide. Various major outer membranes have been described, and VirB9, a type IV secretion system protein, has been recently indicated as a candidate in vaccine development against anaplasmosis. The virB9 gene of an $A$. marginale strain isolated in Paraná, Brazil, was cloned by polymerase chain reaction and sequenced; its cloning into the pETSUMO vector produced a virB9-SUMO-6X His fusion gene construct. This recombinant clone was over-expressed in Escherichia coli BL21 (DE3), and the expressed fusion protein was solubilized with urea and purified with an Ni-NTA column. This method produced a relatively high yield of rVirB9. The deduced amino acid sequence encoded by VirB9 showed $99 \%$ homology to $A$. marginale isolates from St. Maries. rVirB9 was recognized by serum from cattle immunized with PR1 strain and by bovine sera infected with heterologous strains, showing that rVirB9 has conserved epitopes, which suggests that rVirB9 could be useful for the development of a vaccine against anaplasmosis.
\end{abstract}

Key words: Anaplasma marginale; Bovine anaplasmosis; Sequence of VirB9 


\section{INTRODUCTION}

Anaplasma marginale, a tick-borne bacterium, causes in cattle severe anemia, weight loss, abortion, and often death, resulting in significant economic losses in tropical and subtropical regions worldwide (Richey, 1981).

Immunization with purified outer membranes induces protection against acute $A$. marginale infection and disease (Tebele et al., 1991). Some well-characterized outer membrane proteins designated major surface proteins (MSPs), MSP1a, MSP1b, MSP2, MSP3, MSP4, and MSP5, were evaluated as potential candidates for antigens in vaccine production, diagnostic evaluations, and determination of intermolecular relationships (Vidotto et al., 1994; Palmer and McElwain, 1995; Alleman et al., 1997). Antibody responses to outer membrane vaccines are primarily directed against MSP2 and MSP3, but these proteins undergo antigenic variation and do not confer protection (Palmer et al., 2006). Twenty-one other proteins were identified within the outer membrane immunogen based on the proteomic and genomic approach (Lopez et al., 2005). Among the newly described proteins were type IV secretion system (TFSS) proteins VirB9, VirB10 and conjugal transfer protein (CTP) (Lopez et al., 2007).

In other Gram-negative bacteria, TFSS proteins form channels that facilitate the secretion of molecules, and are required for intracellular survival (Christie et al., 2005). The importance of the TFSS in intracellular survival and virulence has been widely documented in Brucella suis, Legionella pneumophila and Helicobacter pylori (Censini et al., 1996; Foulongne et al., 2000; Lammertyn and Anne, 2004). Also, these proteins have been described in rickettsial pathogens, but their functions are less well understood (Ohashi et al., 2002; Felek et al., 2003; Niu et al., 2006).

Because of their surface localization, highly conserved nature, and requirement for intracellular survival, Gram-negative bacterial TFSS proteins are logical targets for immunological intervention (Lopez et al., 2007). A. marginale VirB9, VirB10, and CTP induced B and $\mathrm{T}$ lymphocyte responses in outer membrane-immunized cattle. VirB9 induced the greatest proliferation in $\mathrm{CD}^{+} \mathrm{T}$ cell lines, and VirB9-specific $\mathrm{CD} 4^{+} \mathrm{T}$ cell clones responded to three A. marginale strains, confirming that the VirB9-specific $\mathrm{T}$ cell responses are directed against epitopes in the native protein (Lopez et al., 2007).

The objectives of the present study were the cloning, sequencing and antigenic characterization of VirB9 in an A. marginale strain from Paraná, Brazil.

\section{MATERIAL AND METHODS}

\section{Anaplasma marginale strain and serum}

DNA extraction from parasitized blood of splenectomized cattle and infected with the PR1 strain was performed according to the protocol of the Puregene Genta System ${ }^{\circledR}$.

\section{Cloning of the virB9 gene and DNA sequence analysis}

DNA from the PR1 A. marginale isolate was used to amplify the virB9 gene by polymerase chain reaction (PCR). A pair of primers was constructed according to the sequence of GenBank VirB9 F (5'-ATGAATTTCTATAAAAACTTGCTTGCG-3') and VirB9 R (5'-CTAAAGCACCGTATTCACTACTTCGAC-3'). 
PCR was carried out in a total volume of $50 \mu \mathrm{L}$ containing $50 \mathrm{ng}$ DNA template, $1 \mu \mathrm{L}$ each of the primers at $20 \mathrm{pmol}$, and $200 \mu \mathrm{M}$ of each deoxynucleoside triphosphate (Invitrogen Life Technologies). PCR conditions were as follows: $94^{\circ} \mathrm{C}$ for 5 min followed by 30 cycles of $94^{\circ} \mathrm{C}$ for $1 \mathrm{~min}$, annealing at $55^{\circ} \mathrm{C}$ for $1 \mathrm{~min}$, and $68^{\circ} \mathrm{C}$ for $1 \mathrm{~min}$, followed by a final extension at $68^{\circ} \mathrm{C}$ for $7 \mathrm{~min}$ in a thermal cycler (Gene Amp PCR System 9700/Perkin Elmer). The amplified DNA was visualized on 1.0\% agarose gels stained with ethidium bromide. The 100-bp ladder (Promega, Madison, WI, USA) was used as a standard for determining the molecular mass of PCR products. PCR products were quantified and $20 \mathrm{ng}$ was used as insert in the pETSUMO ${ }^{\circledR}$ vector $(5.5 \mathrm{~kb})$ (Invitrogen, Carlsbad, CA, USA).

Chemically competent $E$. coli host strain TOP10 cells (Invitrogen) were then transformed with $3 \mu \mathrm{L}$ of the cloning reaction. Next, $200 \mu \mathrm{L}$ of transformation was spread on selective plates containing $100 \mu \mathrm{g}$ ampicillin and incubated at $37^{\circ} \mathrm{C}$ overnight. These positive clones were grown in LB containing ampicillin before extraction of the plasmid by alkaline lysis (Sambrook et al., 1989). The presence of vir $B 9$ inserts was confirmed by restriction digestion of recombinant plasmids with ApaI, and by PCR using SUMO forward (5'-AGATTCTTGTACGACGGTATTAG-3') T7 reverse (5'-TAGTTATTGCTGAGCGGTGG-3') and VirB9 primers.

The virB9 gene was sequenced using BigDye Terminator (Applied Biosystems, CA, USA) and the gene primers. The sequences were submitted to BLAST through the NCBI website (http://www.ncbi.nlm.nih.gov/) to check sequence identity. DNA and amino acid sequence analysis were carried out with the computational programs "CAP3 Contig Assembly Program" and "Clustal W (1.81) Multiple Sequence Alignments" and "Six Frame Translation of Sequence".

\section{Expression of virB9 gene in $E$. coli strain and purification of rVirB9}

E. coli BL21 was transformed with the recombinant plasmid pETSUMO-virB9. The BL21/pETSUMO-virB9 strain was grown to an $\mathrm{OD}_{600 \mathrm{~nm}}$ of 0.8 . Isopropyl-1- $\beta-\mathrm{D}$ thiogalactopyranoside (IPTG; Invitrogen Life Technologies) was then added to $1 \mathrm{mM}$, and aliquots were removed at different times to choose the best time for expression. The cells were collected by centrifugation, and expression was determined in soluble and insoluble fractions on $12 \%$ SDS-PAGE gels.

For $\mathrm{rVirB} 9$ purification, the BL21/pETSUMO-virB9 strain was grown for $4 \mathrm{~h}$ at $37^{\circ} \mathrm{C}$. The cells were collected by centrifugation and incubated in buffer containing $6 \mathrm{M}$ guanidine- $\mathrm{HCl}, 20 \mathrm{mM} \mathrm{NaPO}_{4}, 10 \mathrm{mM}$ Tris- $\mathrm{HCl}, \mathrm{pH} 7.8\left(100 \mathrm{mM} \mathrm{NaH}_{2} \mathrm{PO}_{4}, 10 \mathrm{mM}\right.$ Tris$\mathrm{HCl}, 8 \mathrm{M}$ urea, $\mathrm{pH} 8.0$ ) for $1 \mathrm{~h}$ at room temperature to assure thorough cell lysis, and the cell lysate was sonicated on ice with three 5-s pulses at high intensity. The lysate was then centrifuged at 10,000 $\mathrm{g}$ for $30 \mathrm{~min}$, and the supernatant was transferred to Ni-NTA resin $\left(\right.$ Qiagen ${ }^{\circledR}$ ) previously washed with denaturing binding buffer $(8 \mathrm{M}$ urea, $20 \mathrm{mM} \mathrm{NaPO}$, $10 \mathrm{mM}$ Tris-HCl, $\mathrm{pH}$ 7.8). The supernatant and resin were incubated for $1 \mathrm{~h}$ with rotation. After centrifugation at $2000 \mathrm{rpm}$ (microcentrifuge), the resin was washed twice with denaturing binding buffer, and twice with denaturing wash buffer (100 $\mathrm{mM} \mathrm{NaH}_{2} \mathrm{PO}_{4}, 10$ $\mathrm{mM}$ Tris- $\mathrm{HCl}, 8 \mathrm{M}$ urea, $\mathrm{pH}$ 6.3). The protein was eluted using elution buffer (100 mM $\mathrm{NaH}_{2} \mathrm{PO}_{4}, 10 \mathrm{mM}$ Tris-HCl, $8 \mathrm{M}$ urea, $\mathrm{pH}$ 4.5). The protein content of the purified rMSP4 was measured using the Bradford method and analyzed on 12\% SDS-PAGE gels. 


\section{SDS-PAGE and Western blotting}

Lysates and purified proteins were suspended in electrophoresis sample buffer (0.025 M Tris- $\mathrm{HCl}, 2 \%$ SDS, $15 \%$ glycerol, $2.5 \%$ 2-mercaptoethanol, $\mathrm{pH}$ 6.8), boiled for 5 min, and electrophoresed on $8 \%$ SDS-PAGE. The gels were either stained with Coomassie blue or were used for Western blotting. For Western blotting, proteins were transferred onto nitrocellulose membranes (Pharmacia Biotech) (Towbin and Gordon, 1984), and the membranes were blocked in blocking buffer (PBS $+0.1 \%$ Tween $20+5 \%$ nonfat dry milk) for $1 \mathrm{~h}$ at room temperature with agitation. Membranes were washed in PBS-T (PBS $+0.1 \%$ Tween 20$)$ and incubated for $1 \mathrm{~h}$ with bovine polyclonal sera $(1: 2000)$. The membranes were washed and the VirB9 was detected by means of the enhanced chemiluminescence Western Blotting System (Amersham International, Amersham, UK). Protein molecular mass markers (Rainbow ${ }^{\mathrm{TM}}$ colored, Amersham Life Science) were used as standards.

\section{RESULTS AND DISCUSSION}

\section{Cloning and sequencing of virB9 gene}

The genetic and antigenic conservation of a protective protein is important for its efficacy as a vaccine. The TFSS proteins VirB9, VirB10 and CTP are components of the protective $A$. marginale outer membrane fraction and because they are highly conserved due to functional constraints, they may be more appropriate candidates for vaccines than the antigenically variant MSP2 and MSP3 (Lopez et al., 2005, 2007).

In this study, the virB9 (840 bp) from the PR1 A. marginale strain was cloned and sequenced. The colonies obtained from cloning into pETSUMO were screened first by PCR with specific primers for the virB9 gene and the vector. All clones VirB9 $9^{+}$showed the amplicon, and after cleavage of the recombinant plasmid pETSUMO-virB9 from a positive clone with the restriction enzyme HindIII, a 6.4-kb fragment was released corresponding to $5.6 \mathrm{~kb}$ of the vector plus $0.84 \mathrm{~kb}$ of the insert. The cleavage of the pETSUMO-virB9 with ApaI showed two fragments of 4.4 and $2.0 \mathrm{~kb}$, demonstrating the correct position of vir $B 9$ gene.

The complete sequence of virB9 gene amplified from the PR1 A. marginale was deposited in GenBank (accession number 1064466). The analysis of the virB9-coding region from the PR1 strain showed high identity in nucleotides (98\%) with the sequence of virB9 from the St. Maries strain of A. marginale (accession number YP_154362). When the amino acid sequence of VirB9 from the PR1 strain was compared with the St. Maries strain, there was $99 \%$ similarity. Additionally, the St. Maries and Florida strains have complete amino acid identity in VirB9, and the topology prediction algorithm calculated VirB9 to be either an outer membrane protein or surface associated protein (Lopez et al., 2007). These predictions are consistent with surface localization of similar TFSS proteins in other bacteria (Christie et al., 2005).

\section{Expression of virB9 gene in E. coli BL21 and characterization of rVirB9}

The recombinant plasmid pETSUMO-virB9 was used to transform E. coli BL21 
(DE3), a bacterial strain designed for gene expression regulated by the $\mathrm{T} 7$ promoter. This expression vector was chosen based on the presence of sequences encoding six histidine residues, V5 epitope tag and His-Patch thioredoxin. The VirB9 fusion protein should have an estimated size of about $47 \mathrm{kDa}$ on SDS-PAGE. The expected band around $47 \mathrm{kDa}$ was more evident after $4 \mathrm{~h}$ of induction with IPTG (Figure 1A, lane 3). This band was observed in the insoluble fraction or inclusion bodies. Although His-Patch thioredoxin increases the solubility of recombinant proteins, the results showed that rVirB9 is insoluble. The $47-\mathrm{kDa}$ band was absent in the negative control.

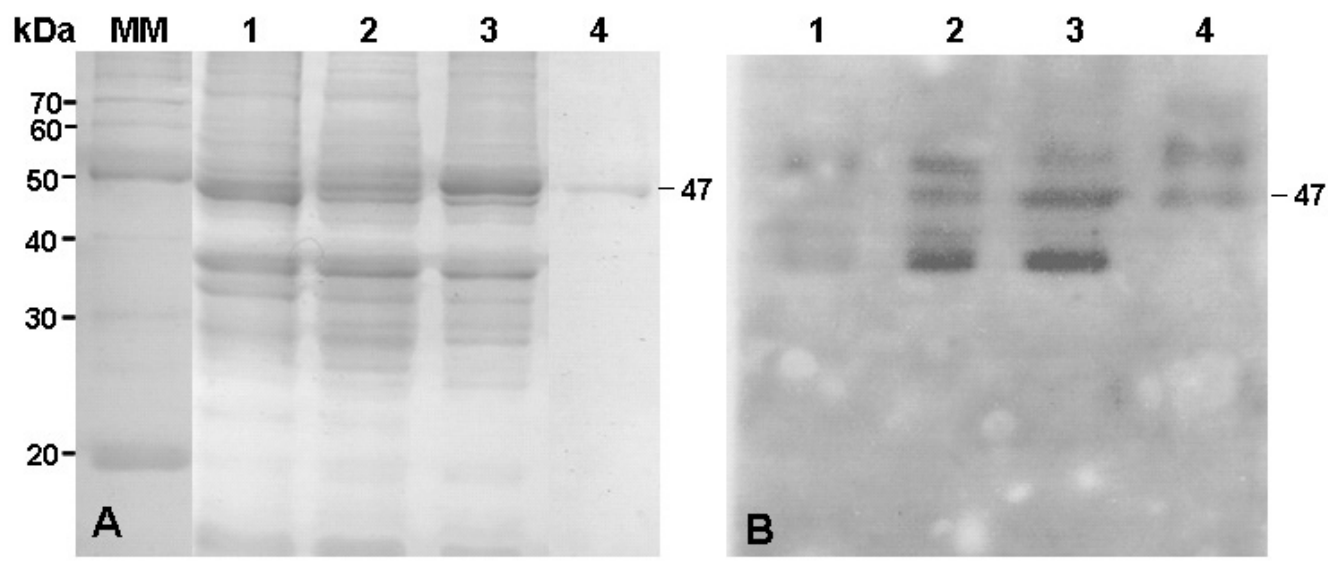

Figure 1. Expression and purification of rVirB9 protein from clone BL21/pETSUMO-virB9. A. 12\% SDS-PAGE stained with Coomassie brilliant blue. B. Western blotting of rVirB9 with homologous serum, polyclonal serum produced against PR1 strain. Lane 1, BL21; lane 2, BL21/pETSUMO-virB9 not induced; lane 3, BL21/pETSUMOvirB9 induced with $1 \mathrm{mM}$ IPTG; lane 4, elution protein. $\mathrm{MM}=$ molecular mass.

rVirB9 was solubilized and purified with the Ni-NTA purification system under denaturing conditions using urea. The targeted 6X His-tag rVirB9 was eluted in fractions (Figure 1A, lane 4). The results obtained from SDS-PAGE showed that rVirB9 was successfully expressed in BL21 (DE3) and purified by means of Ni-NTA.

The polyclonal serum from cattle immunized with PR1 strain of $A$. marginale reacted with a 47-kDa protein from BL21/pETSUMO-virB9 induced by IPTG and with rVirB9 in Western blotting (Figure 1B). Pre-immune serum did not reacted with rVirB9. Additionally, rVirB9 reacted with bovine polyclonal heterologous sera from cattle of other regions of Brazil by Western blotting (Figure 2), showing conserved epitopes and antigenicity. These results agree with those obtained from Lopez et al. (2007), which showed the presence of a conserved gene coding for $\mathrm{rVirB} 9$ and antibody from outer membrane vaccines recognizing recombinant forms of the proteins studied. 


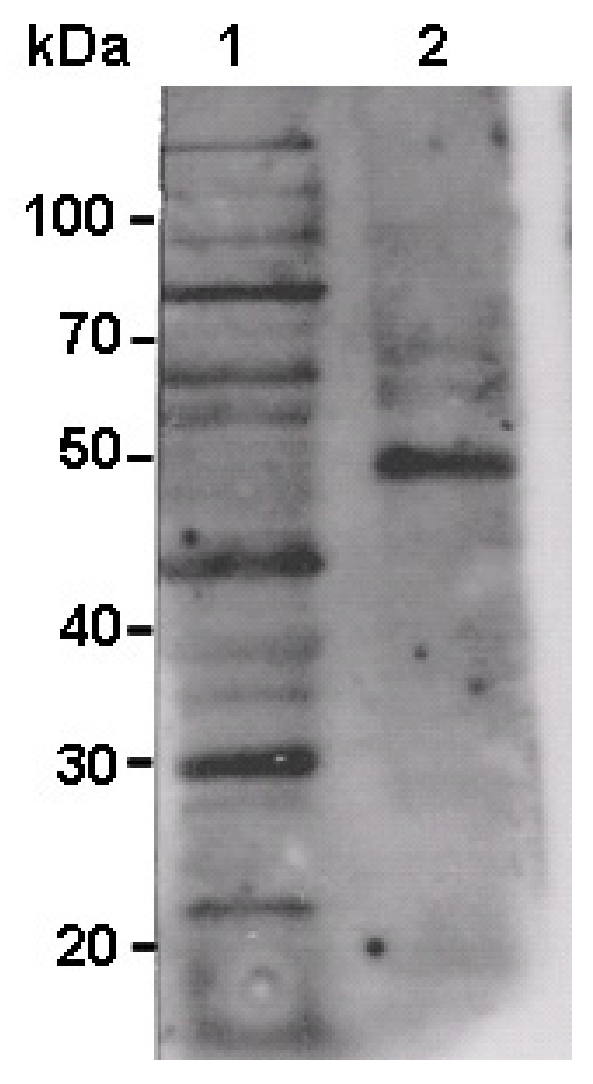

Figure 2. Western blotting of rVirB9 with heterologous serum. Lane 1, BL21 strain; lane 2, eluted VirB9.

In outer membrane-immunized cattle, three $A$. marginale TFSS proteins, VirB9, VirB10, and CTP, elicit significant $\mathrm{CD} 4^{+} \mathrm{T}$ lymphocyte proliferation, IFN- $\gamma$ secretion, and $\mathrm{IgG} 2$ production, immune responses associated with protective immunity (Lopez et al., 2007). However, VirB9 was selected since this antigen was consistently recognized by memory $\mathrm{T}$ cells and induced strong proliferative responses from all cattle tested (Lopez et al., 2007). Transcriptional analyses of TFSS genes in E. chaffeensis and A. phagocytophilum have shown that VirB8, VirB9, VirB10, VirB11, and VirD4 are transcribed polycistronically (Ohashi et al., 2002). However, in E. canis, VirB9 is expressed throughout various stages of infection, and is antigenic in E. canis-infected dogs (Felek et al., 2003). Additionally, elevated levels of VirB9 were expressed during replication of A. phagocytophilum within neutrophils, whereas basal levels of VirB9 were expressed upon neutrophil lysis (Niu et al., 2006), demonstrating differential levels of expression of TFSS proteins during the mammalian infection cycle.

This study shows that rVirB9 is highly conserved and that the rVirB9 possesses conserved epitopes and maintained antigenicity, suggesting its use for subunit vaccine development. 


\section{ACKNOWLEDGMENTS}

The authors are grateful to Elizabeth R.M. Marana for technical assistance.

\section{REFERENCES}

Alleman AR, Palmer GH, McGuire TC, McElwain TF, et al. (1997). Anaplasma marginale major surface protein 3 is encoded by a polymorphic, multigene family. Infect. Immun. 65: 156-163.

Bradford MM (1976). A rapid and sensitive method for the quantitation of microgram quantities of protein utilizing the principle of protein-dye binding. Anal. Biochem. 72: 248-254.

Censini S, Lange C, Xiang Z, Crabtree JE, et al. (1996). cag, a pathogenicity island of Helicobacter pylori, encodes type I-specific and disease-associated virulence factors. Proc. Natl. Acad. Sci. U. S. A. 93: 14648-14653.

Christie PJ, Atmakuri K, Krishnamoorthy V, Jakubowski S, et al. (2005). Biogenesis, architecture, and function of bacterial type IV secretion systems. Annu. Rev. Microbiol. 59: 451-485.

Felek S, Huang H and Rikihisa Y (2003). Sequence and expression analysis of virB9 of the type IV secretion system of Ehrlichia canis strains in ticks, dogs, and cultured cells. Infect. Immun. 71: 6063-6067.

Foulongne V, Bourg G, Cazevieille C, Michaux-Charachon S, et al. (2000). Identification of Brucella suis genes affecting intracellular survival in an in vitro human macrophage infection model by signature-tagged transposon mutagenesis. Infect. Immun. 68: 1297-1303.

Lammertyn E and Anne J (2004). Protein secretion in Legionella pneumophila and its relation to virulence. FEMS Microbiol. Lett. 238: 273-279.

Lopez JE, Siems WF, Palmer GH, Brayton KA, et al. (2005). Identification of novel antigenic proteins in a complex Anaplasma marginale outer membrane immunogen by mass spectrometry and genomic mapping. Infect. Immun. 73: 8109-8118.

Lopez JE, Palmer GH, Brayton KA, Dark MJ, et al. (2007). Immunogenicity of Anaplasma marginale type IV secretion system proteins in a protective outer membrane vaccine. Infect. Immun. 75: 2333-2342.

Niu H, Rikihisa Y, Yamaguchi M and Ohashi N (2006). Differential expression of VirB9 and VirB6 during the life cycle of Anaplasma phagocytophilum in human leucocytes is associated with differential binding and avoidance of lysosome pathway. Cell Microbiol. 8: 523-534.

Ohashi N, Zhi N, Lin Q and Rikihisa Y (2002). Characterization and transcriptional analysis of gene clusters for a type IV secretion machinery in human granulocytic and monocytic ehrlichiosis agents. Infect. Immun. 70: 2128-2138.

Palmer GH and McElwain TF (1995). Molecular basis for vaccine development against anaplasmosis and babesiosis. Vet. Parasitol. 57: 233-253.

Palmer GH, Futse JE, Knowles DP Jr and Brayton KA (2006). Insights into mechanisms of bacterial antigenic variation derived from the complete genome sequence of Anaplasma marginale. Ann. N. Y. Acad. Sci. 1078: 15-25.

Richey EJ (1981). Bovine anaplasmosis. In: Current veterinary therapy: food animal practice (Howard RJ, ed.). Saunders, Philadelphia, 767-772.

Sambrook J, Fritsch EF and Maniatis T (1989). Molecular Cloning - A Laboratory Manual. Cold Spring Harbor Laboratory Press, Cold Spring Harbor.

Tebele N, McGuire TC and Palmer GH (1991). Induction of protective immunity by using Anaplasma marginale initial body membranes. Infect. Immun. 59: 3199-3204.

Towbin H and Gordon J (1984). Immunoblotting and dot immunobinding-current status and outlook. J. Immunol. Methods 72: 313-340.

Vidotto MC, McGuire TC, McElwain TF, Palmer GH, et al. (1994). Intermolecular relationships of major surface proteins of Anaplasma marginale. Infect. Immun. 62: 2940-2946. 